\title{
Dvejopo kuro variklio eksergijos balanso palyginamieji tyrimai
}

\section{Vygintas Daukšys,}

\section{Sergëjus Lebedevas}

Klaipédos universitetas, Jüros technologiju ir gamtos mokslu fakultetas, Jürų inžinerijos katedra, Bijūnų g. 17, 91225 Klaipèda

El.paštas: vygintasdauksys@gmail.com; sergejus.lebedevas@ku.lt
Straipsnyje pateikti dyzelinio variklio „4ČN 79,5/95,5“, konvertuoto veikimui naudojant dvejopas dyzelinas (D)-gamtinès dujos $(\mathrm{GD})$ kurą $(\mathrm{D} / \mathrm{GD})$, kogeneracinio ciklo energetinių parametrų tyrimų rezultatai. Tyrimų tikslu tapo variklio, veikiančio naudojant $\mathrm{D}$ ir dvejopą (D/GD) kurą, kogeneracinio ciklo antrinių energijos išteklių (išmetamųjų dujų ir aušinančio kontūro vandens) energijos efektyvumo panaudojimo rodiklių palyginamoji analizè. Eksergijos balanso energetinès sudedamosios ištirtos plačiuose apkrovos $\left(p_{m e}=1,98-5,99\right.$ bar) ir D/GD sudèties (100/0-20/80) bei variklio reguliavimo parametru pasikeitimo diapazonuose. Eksergijos balanso suminio naudingumo koeficiento $\left(\eta_{E \times \Sigma}\right)$, ivertinančio elektros ir šiluminès energijos panaudojimo efektyvumą, sumažejimas neviršijo 3-4 \% ir $22 \%$ atitinkamai aukštos ir žemos jègainès apkrovos režimuose. Mažejant eksergijos panaudojimo efektyvumo rodikliams $\left(\eta_{E x e}, \eta_{E x \Sigma}\right.$ ), absoliutus eksergijos potencialas praktiniam panaudojimui dèl šiluminès energijos sudedamosios augimo dideja nuo 3-18 \% aukštos apkrovos režimuose ir iki 14-58 \% žemos apkrovos režimuose. Nustatyta, kad santykinai mažesni absoliučių eksergijos balanso rodiklių pasikeitimai būdingi dyzelinèms jègainèms su didesne indikatorinio proceso dinamika. Tai leidžia teigti, kad kogeneracinio ciklo energetinių sudedamųu gerinimo potencialas yra didinant indikatorinio proceso dinaminius rodiklius (pvz., ankstinant dyzelino ịpurškimo paskubos kampą $\varphi_{i n j}$ ).

Raktažodžiai: dyzelinis variklis, dvejopas kuras, eksergija

\section{IVADAS}

Paskutiniaisiais dešimtmečiais pagrindinèmis Europos Sajungos transporto pletros kryptimis tapo energijos panaudojimo efektyvumo didinimas, aplinkos taršos kenksmingais komponentais ir šiltnamio efektą sukeliančių dujų išmetimo mažinimas [1-3]. Vienas iš efektyviausių proble- mos sprendimo būdų yra transporto ir mažosios energetikos sektoriuose plačiai paplitusių dyzelinių variklių (DV) konvertavimas iš dyzelino (D) ì veikimą naudojant gamtines dujas (GD) arba dvejopą dyzelinas-gamtinès dujos kurą (D/GD) ir antrinių DV energijos šaltinių, prarandamų su išmetamosiomis dujomis bei $\mathfrak{i}$ aušinimo sistemą, panaudojimas kogeneracinèms jëgainèms [4]. 
DV, konvertuotų veikimui GD, skirta nemažai eksperimentinių, skaitinių ir matematinio modeliavimo tyrimų, pavyzdžiui, dviejų degalų mišinio krovininio transporto variklio tyrimuose [5] pasiektas $\mathrm{NO}_{\mathrm{x}}$ sumažinimas iki 6 kartų, palyginti su dyzeliniu ciklu, anglies monoksido CO $-83 \%$, tuo pat metu degalų sąnaudoms mažejant 7,5 \%. Vidutinių sūkių Wartsila firmos 20DF laivo paskirties variklyje be antrinių kenksmingų komponentų valymo technologijų panaudojimo (angl. SCR - Selective Catalytic Reduction technology), jam funkcionuojant GD, pasiektas galiojančio Marpol 73/79 VI priedo standarto redakcijos Tier III normatyvų realizavimas [6]. Palyginti su naftos kilmès degalais, teoriniu požiūriu, GD elementinès cheminès sudeties anglies-vandenilio $\mathrm{C} / \mathrm{H}$ santykis palankesnis mažinant šiltnamio efektą sukeliančių dujų $\mathrm{CO}_{2}$ emisiją ketvirtadaliu $[7,8]$.

Dauguma eksperimentinių ir matematinio modeliavimo tyrimų paremta tyrimų objektais, kuriuos sudaro šiuolaikiniai DV, turintys aukšto slègio akumuliacinę (angl. common rail) degalų tiekimo sistemą. Ši sistema pasižymi plačiomis kuro ịpurškimo parametrų reguliavimo ir optimizavimo galimybemis [9]. Nepalyginamai mažiau tyrimų yra atlikta su DV, turinčiais tradicinę kuro ipurškimo sistemą (angl. conventional fuel injection system), nors jų dalis eksploatuojamame DV parke iki šiol yra gana didelè [10]. Taip pat santykinai mažai tyrimų skirta dujinių ir dvejopo kuro variklių kogeneracinio ciklo energetinio efektyvumo rodiklių analizei, ypač variklių su tradicine degalų ịpurškimo sistema [11].

Klaipedos ir Vilniaus Gedimino technikos universitetų mokslininkų atlikti kompleksiniai DV „4ČN 79,5/95,5“ su tradicine kuro sistema konvertavimo veikimui naudojant D/GD kurą eksperimentiniai ir skaitiniai tyrimai [12]. Atlikta variklio energetinių ir ekologinių rodiklių, indikatorinio proceso parametrų ir charakteristikų palyginamoji analizè. Itvertintas vienzonio matematinio modelio panaudojimo efektyvumas, prognozuojant eksploatacinius parametrus varikliui veikiant su dvejopu kuru. Vienas iš pagrindinių aspektų yra kogeneracinio ciklo energetinio efektyvumo rodikliu palyginamieji tyrimai.

Straipsnyje pateikti variklio kogeneracinio ciklo energetinio efektyvumo rodiklių palyginamųjų tyrimų esminiai rezultatai.

\section{Metodologiniai aspektai}

Tyrimo objektu tapo DV „4ČN 79,5/95,5“ su tradicine kuro ịpurškimo sistema, kurios pagrindiniai parametrai pateikti 1 lentelèje.

\section{1 lentelè. Variklio parametrai}

\begin{tabular}{cc}
\hline Modelis & 4ČN79,5/95,5 \\
\hline Darbinis tūris, $\mathrm{cm}^{3}$ & 1896 \\
\hline Diametras $\times$ eiga, $\mathrm{mm}$ & $79,5 \times 95,5$ \\
\hline Maksimali galia, $\mathrm{kW} / \mathrm{min}^{-1}$ & $66 / 4000$ \\
\hline Sukimo momentas, Nm/min ${ }^{-1}$ & $180 / 2000-2500$ \\
\hline Aušinimo tipas & Skysčiu aušinamas \\
\hline Kuro tiekimo sistema & $\begin{array}{c}\text { Tiesioginis } \\
\text { ipurškimas }\end{array}$ \\
\hline Cilindrų skaičius & 4 eilèje \\
\hline Suspaudimo laipsnis & $19,5: 1$ \\
\hline Oro tiekimas & Turbokompresorius \\
\hline
\end{tabular}

Eksperimente panaudoto dvejopo D/GD kuro komponentų, t. y. dyzelino ir gamtinių dujų, savybès atitinka EN 590 ir ISO 6976:1995 standartus (2 lentelè).

\section{2 lentelè. Kuro parametrai}

\begin{tabular}{|c|c|c|}
\hline Kuro tipas & Gamtinès dujos & Dyzelinas \\
\hline Tankis, kg/m³) & 0,74 & 829,0 \\
\hline Cetaninis skaičius & - & 49 \\
\hline $\begin{array}{c}\text { Žemutinè } \\
\text { energetinè vertè, } \\
\mathrm{MJ} / \mathrm{kg}\end{array}$ & 51,7 & 42,8 \\
\hline $\begin{array}{l}\text { Klampa, } \\
\text { cSt } 40^{\circ} \mathrm{C}\end{array}$ & - & 1,485 \\
\hline $\mathrm{H} / \mathrm{C}$ santykis & - & 1,907 \\
\hline \multirow[t]{5}{*}{$\begin{array}{c}\text { Komponentai, } \\
\% \text { vol. }\end{array}$} & $\begin{array}{c}\text { Meta- } \\
\text { nas }-91,97\end{array}$ & Anglis 86,0 \\
\hline & Etanas - 5,75 & Vandenilis - 13,6 \\
\hline & Propanas $-1,30$ & Deguonis - 0,4 \\
\hline & Butanas $-0,281$ & \\
\hline & $\begin{array}{c}\text { Azotas }-0,562 \\
\text { Anglies } \\
\text { dioksidas }-0,0\end{array}$ & \\
\hline
\end{tabular}

Variklio išoriniam šilumos balansui skaičiuoti buvo suformuota metodika, apjungianti klasikines analitines išraiškas, kai variklis veikia naudodamas skystąji kurą - degalus arba dujinį kurą [13]. 
Pavyzdžiui, nustatant šilumą, prarandamą su išmetamosiomis dujomis $Q_{i d}$, vieno iš pagrindinio parametro, t. y. išmetamųjų dujų, molių kiekio $\mathrm{M}_{2}$ skaičiavimo lygtis susideda iš dviejų skystam ir dujiniam kurui atitinkančių struktūros dalių:

$$
\begin{aligned}
& M_{2}=M_{2}^{D} \cdot \frac{G_{f}^{D}}{\left(G_{f}^{D}+G_{f}^{D K} \cdot k\right)}+M_{2}^{D K} \cdot \frac{G_{f}^{D K} \cdot k}{\left(G_{f}^{D}+G_{f}^{D K} \cdot k\right)} \\
& +\left(\alpha_{\Sigma}-1\right) \cdot L^{D / D K}+0,79 L^{D / D K}+(1-k) \cdot \frac{G_{f}^{D K}}{\left(G_{f}^{D}+G_{f}^{D K} \cdot k\right)}= \\
& \frac{C}{12} \cdot \frac{G_{f}^{D}}{\left(G_{f}^{D}+G_{f}^{D K} \cdot k\right)}+\frac{1}{16} \cdot \frac{G_{f}^{D K} \cdot k}{\left(G_{f}^{D}+G_{f}^{D K} \cdot k\right)} \\
& +M_{\mathrm{CO}_{2}} \cdot \frac{G_{f}^{D K}}{\left(G_{f}^{D}+G_{f}^{D K} \cdot k\right)} \cdot \frac{(1-k)}{k}+\frac{H}{2} \cdot \frac{G_{f}^{D}}{\left(G_{f}^{D}+G_{f}^{D K} \cdot k\right)} \\
& +\frac{2}{16} \cdot \frac{G_{f}^{D K} \cdot k}{\left(G_{f}^{D}+G_{f}^{D K} \cdot k\right)}+\left(\alpha_{\Sigma}-1\right) \cdot L^{D / D K}+0,79 L^{D / D K} ;
\end{aligned}
$$

čia $M_{2}^{D}$ ir $M_{2}^{D K}$ - dyzelino ir dujinio kuro išmetamųjų dujų molių skaičius; $G_{f}^{D}$ ir $G_{f}^{D K}$ - kuro sunaudojimas $\mathrm{kg} / \mathrm{h} ; k$ - koeficientas, ịvertinantis metano dali dujiniame kure; $\alpha_{\Sigma}-$ absoliutus oro pertekliaus koeficientas; $L^{D / D K}$ - stechiometrinè dvejopo kuro konstanta; $M_{\mathrm{CO}_{2}}$ - anglies dioksido molių skaičius.

$\mathrm{CO}_{2}$ ir $\mathrm{H}_{2} \mathrm{O}$ molių skaičiai nustatomi kaip skystojo ir dujinio kuro degimo produktai:

$$
\begin{aligned}
& \frac{C}{12} \cdot \frac{G_{f}^{D}}{\left(G_{f}^{D}+G_{f}^{D K} \cdot k\right)}+\frac{1}{16} \cdot \frac{G_{f}^{D K} \cdot k}{\left(G_{f}^{D}+G_{f}^{D K} \cdot k\right)} \\
& +M_{\mathrm{CO}_{2}} \cdot \frac{G_{f}^{D K}}{\left(G_{f}^{D}+G_{f}^{D K} \cdot k\right)} \cdot \frac{(1-k)}{k}, \\
& \frac{H}{2} \cdot \frac{G_{f}^{D}}{\left(G_{f}^{D}+G_{f}^{D K} \cdot k\right)}+\frac{2}{16} \cdot \frac{G_{f}^{D K} \cdot k}{\left(G_{f}^{D}+G_{f}^{D K} \cdot k\right)} .
\end{aligned}
$$

Eksergijos balanso sudedamosios dalys nustatytos pagal [14] siūlymus, grafiškai pavaizduotos 1 pav., kur: $E x_{f}$ - pradinè (įeinanti) eksergija, susidedanti iš kuro ir oksidatoriaus eksergijos; $E x_{e}-$ mechaninio darbo eksergija; $E x_{d}-$ degimo eksergija; $E x_{i d}$ - išmetamųjų deginių eksergija; $E x_{v}$ - aušinimo kontūro vandens eksergija; $E x_{a}$ - tepimo kontūro alyvos eksergija; $\mathrm{Ex}_{\text {lik }}-\mathrm{ek}$ sergijos likutis; $N_{e}$ - jègainès efektyvioji galia; $T_{0}$ - aplinkos temperatūra; $\bar{T}_{1}$ - vidutinè degimo temperatūra; $\bar{T}_{2}$ - vidutinè termodinaminè išmetamųjų deginių temperatūra; $\bar{T}_{v}$ - vidutinè termodinaminè aušinančio kontūro vandens temperatūra; $\bar{T}_{a}$ - vidutine termodinaminè tepimo sistemos alyvos temperatūra; $Q_{v}$ - šilumos balanso energija, patenkanti i aušinimo kontūrą; $Q_{a}$ - šilumos balanso energija, patenkanti ị tepimo sistemą.

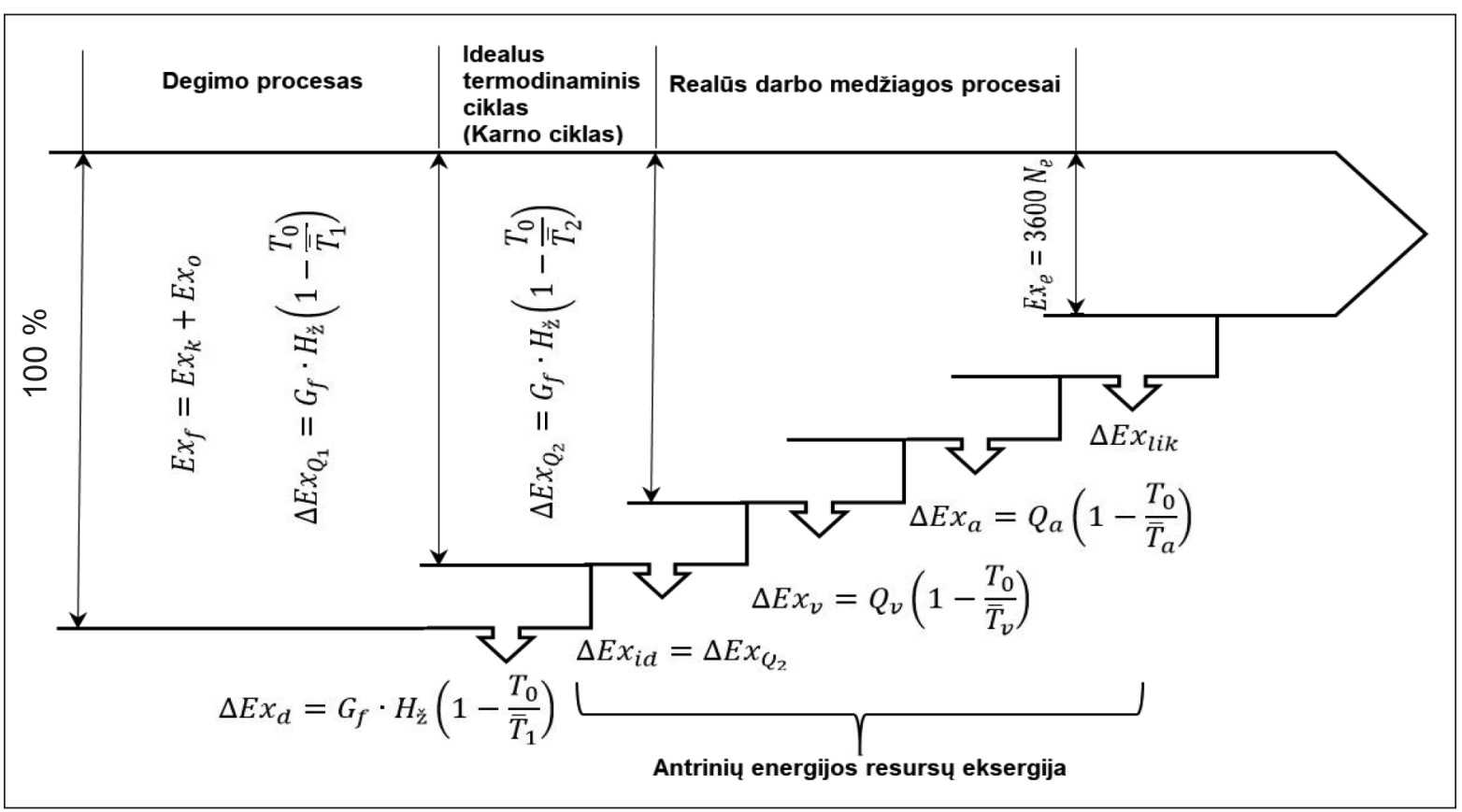

1 pav. Šiluminio variklio eksergijos balanso principinè schema [14] 
Skirtingai nei pateikta šaltinyje [14], vidutinè degimo temperatūra $\bar{T}_{1}$ buvo nustatyta iš realaus eksperimento indikatorinių diagramų (slègio cilindre priklausomybė nuo alkūninio veleno pasukimo kampo).

Tyrimai atlikti varikliui veikiant plačiame apkrovos diapazone ( $p_{m e}=1,98-5,99$ bar), naudojamo dvejopo kuro sudèties (D/GD = 100/0;60/40; 40/60; 20/80), skysto kuro ịpurškimo paskubos kampo $\left(\varphi_{i n j}=-1 ;-4 ;-7 ;-10 ;-13^{\circ}\right.$ alkūninio veleno pasisukimo kampas (avpk) iki viršutinio rimties taško - VRT) diapazonuose. Straipsnyje pateikti tik eksperimento diapazono kraštiniu rezultatų duomenys ( $\varphi_{i n j}=-1--13^{\circ}$ avpk iki VRT), $(\mathrm{D} / \mathrm{GD}=100 / 0 ; 20 / 80)$. Aplinkos temperatūra $T_{0}=298 \mathrm{~K}$.

\section{TYRIMO REZULTATAI IR JŲ APTARIMAS}

Išsamiai vertinant dvejopo kuro variklio energijos ir eksergijos balansą, atliktų skaičiavimų rezultatai parodè skirtingą energetinių dedamųjų kokybini pasiskirstymą. Šilumos balanso vertinimas nustatė energijos persiskirstymą lyginant su variklio veikimu naudojant dyzelinị kurą, o eksergijos balanso vertinimas parodè realiai galimą panaudoti antrinès energijos resursą, varikliui dirbant su dvejopu kuru. Pagrindiniai skaičiavimų rezultatai pateikti 3 lenteleje.

Šilumos ir eksergijos balanso efektinis naudingumo koeficientas $\left(\mathrm{NVK} \eta_{e}=\eta_{E x e}\right)$ mažèja didèjant energetinei GD daliai dvejopame kure, o ypač esant žemam apkrovos režimui ( $p_{m e}=1,98 \mathrm{bar}$ ). Pilotinès dyzelino porcijos įpurškimo paskubos kampo paankstinimas nuo $-1^{\circ}$ avpk iki $-13^{\circ}$ avpk prieš VRT nedidele dalimi kompensuoja energetinio efektyvumo rodiklius $\eta_{e}=\eta_{\text {Exe. }}$ Rezultatai pateikti (2 pav.).

Pateikti duomenys leidžia racionaliai derinti dvejopo kuro sudèti jègainei veikiant plačiame apkrovos diapazone, gaminant elektros energiją esant panašiam efektyvumui, jai funkcionuojant D: nominalios galios režimuose naudoti dvejopą kurą su kuo didesne GD dalimi, o mažos apkrovos režimuose atvirkščiai - pageidautina veikti grynu dyzelinu arba su minimalia GD dalimi.

Analogiška tendencija būdinga suminès eksergijos NVK $\left(\eta_{E x \Sigma}\right)$ pasikeitimui.

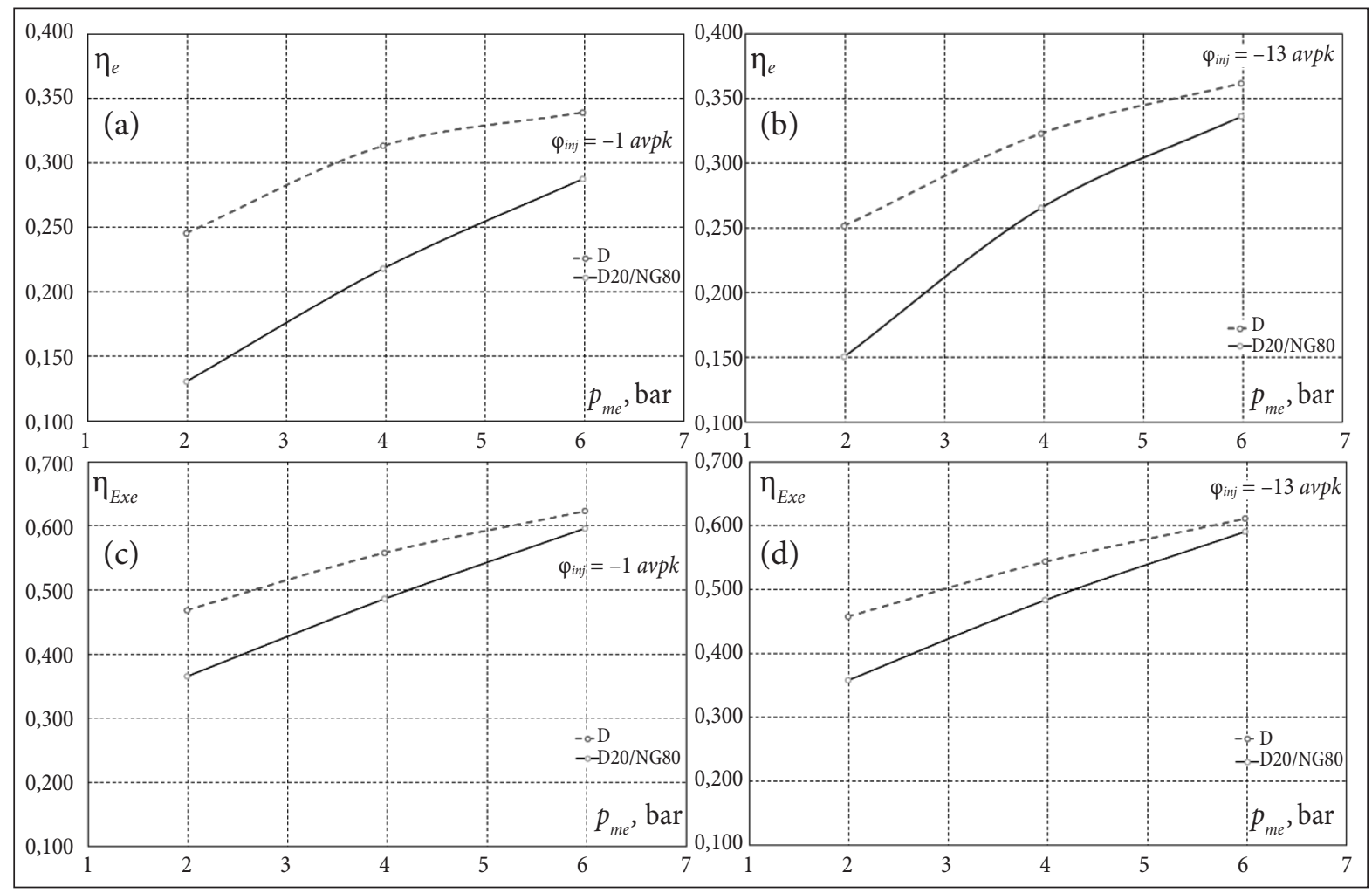

2 pav. Efektinio ir suminio eksergijos naudingumo koeficientų palyginimas, kai kogeneracinè jėgainè veikia naudodama dyzelinį ir dvejopą D/GD kurą 


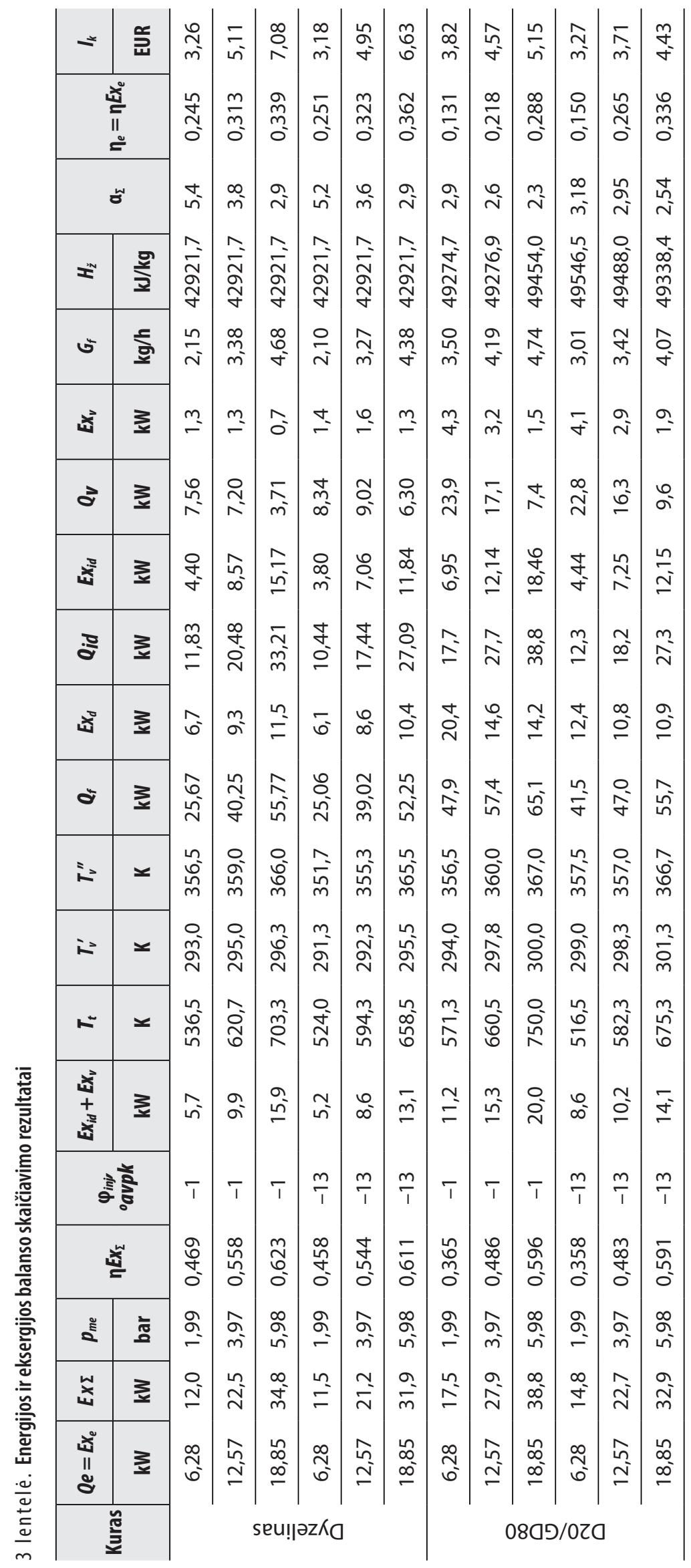




$$
\eta_{E X \Sigma}=\left(\frac{E x_{i d}+E x_{v}+E x_{e}}{E x_{f}}\right) ;
$$

čia $E x_{f}=Q_{f}$ - visa su kuru ir oksidatoriumi įnešama energija.

Mažos apkrovos režimuose $\left(\eta_{E x \Sigma}\right)$ reikšmè naudojant dyzeliną 0,458-0,469 yra 22\% didesnè nei dvejopą kurą D/GD (20/80). Didelès apkrovos režimuose $\eta_{\mathrm{Ex \Sigma}}$ reikšmès skiriasi mažai: naudojant dyzeliną - 0,611-0,623, o D/GD (20/80) - 0,5910,596 . Tokiu būdu kogeneracinio ciklo bendras elektros ir šilumos energijos gaminimo efektyvumas, veikiant didele GD energetine dalimi dvejopame kure (D/GD (20/80 ir daugiau), aukštos apkrovos režimuose praktiškai nenusileidžia naudojant dyzeliną.

Kita vertus, absoliutus kogeneracinio ciklo efektyvumas, išreikštas suminès eksergijos vienetais $\left(E x_{e}+E x_{i d} E x_{v}\right)$, visame ištirtame apkrovos diapazone yra reikšmingai didesnis, varikliui naudojant dvejopą kurą D/GD (20/80) (3a pav.). Palyginti su dyzelino naudojimu, didèja energetinis potencialas, išmetamųjų deginių ir aušinimo kontūro vandens, antrinès energijos panaudojimas ( $3 \mathrm{~b}$ pav.).

Gautų rezultatų analizė rodo, kad esant mažesnei dinamikai pasiekiamas geresnis $E x$ efektas, t. y. geresnis praktinis efktas, nors $\eta_{e}$ ir $\eta_{E x \Sigma}$ rodikliai yra prastesni.

Kadangi $E x_{\Sigma}=E x_{e}+E x_{(i d+v)}$ tai $E x_{\Sigma}$ padidèjimo efektas gaunamas dèl $E x_{(i d+v)}$ didejimo. Tai aktualu kogeneracinę jẻgainę eksploatuojant šaltuoju metų sezonu.

Turint $E x_{\Sigma}, \eta_{E x \Sigma}, E x_{(i d+v)}$ duomenis $\left(p_{m e}=1,98-\right.$ 5,99 bar) ir D/GD (20/80), grafiko lauke užtikrinamos plačios galimybès parenkant lankstų ko- generacinès jègainès veikimo būdą tiek $\mathrm{D}$, tiek ir D/GD (su konvencine kuro sistema). Pavyzdžiui, šaltuoju metų laikotarpiu, kai daugiau šilumos energijos sunaudojama patalpų šildymui, racionalu nedidinant jègainès $N_{e}$ (galios elektros energijos gamybai) ją konvertuoti i D/GD, nes jegainei naudojant dvejopą kurą D/GD smarkiai didejja $E x_{(i d+v)}$; sudaro apie $31 \%$.

Kogeneracinès jègainès ekonomini rentabilumą didžiaja dalimi lemia išlaidos kurui. Jègainès kogeneraciniame cikle remiantis nuostata, kad $p_{m e}=$ tiek D, tiek D/GD, $\eta_{e}$ kitimas yra susijęs su skirtingomis kuro sąnaudomis. Vertinant finansinę išraišką, reikia remtis D ir GD kuro kainų skirtumu. Varikli konvertuojant veikti naudojant dvejopą kurą, suminès eksergijos $E x_{\Sigma}$ ir išlaidų kurui $\left(I_{k}\right)$ pasikeitimo dinamika skiriasi. Itakos tam turi bent du veiksniai: dyzelino ir dvejopo D/GD kuro kainos kitimo santykis, kuris priklauso nuo dvejopo kuro sudèties, bei skirtinga suminès eksergijos ir kuro sąnaudų $G_{f}$ pasikeitimo dinamika. Todèl dvejopu kuru veikiančios kogeneracinès jègainès ekonominio rentabilumo vertinimui panaudota suminés eksergijos vieno vieneto kaina (K). Remiantis interneto šaltinių (degalukainos.lt ir SGdujos.lt) duomenimis, dyzelino ir gamtiniu dujų kainos atitinka 1,04 EUR/l ir 0,77 EUR/m³, paskaičiuota kogeneracinio ciklo suminès eksergijos $\left(E x_{e}+E x_{i d}+E x_{v}\right)$ vieneto kaina (K), EUR/kJ dviem atvejais: funkcionuojant D ir D/GD (20/80) (4 pav.).

Apibendrinant (K) skaičiavimus, plačiai dvejopo kuro sudéčiai (D/GD - 100/0; 60/40; 40/60; 20/80) sudarytas ekonominio efektyvumo lauko grafikas $p_{m e}$ ir D/GD koordinačių sistemoje (5 pav.)

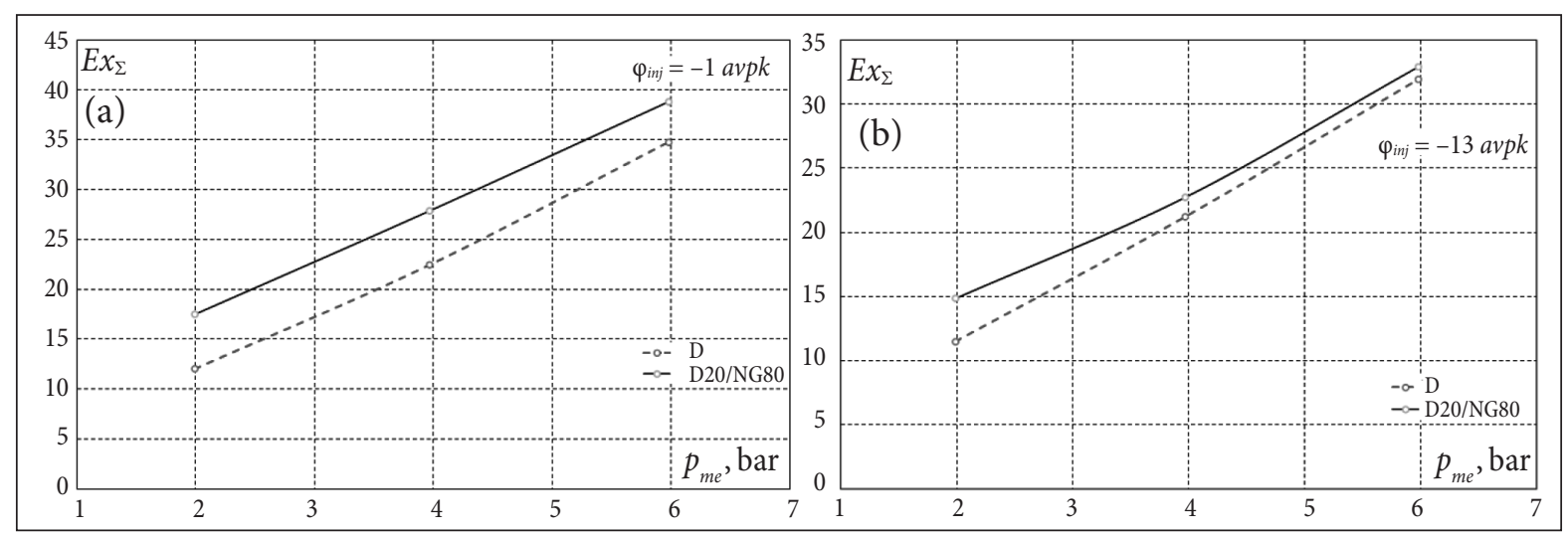

3 pav. Suminès eksergijos efektyvumo palyginimas kogeneracinei jėgainei naudojant dyzeliną ir dvejopą D/GD kurą 

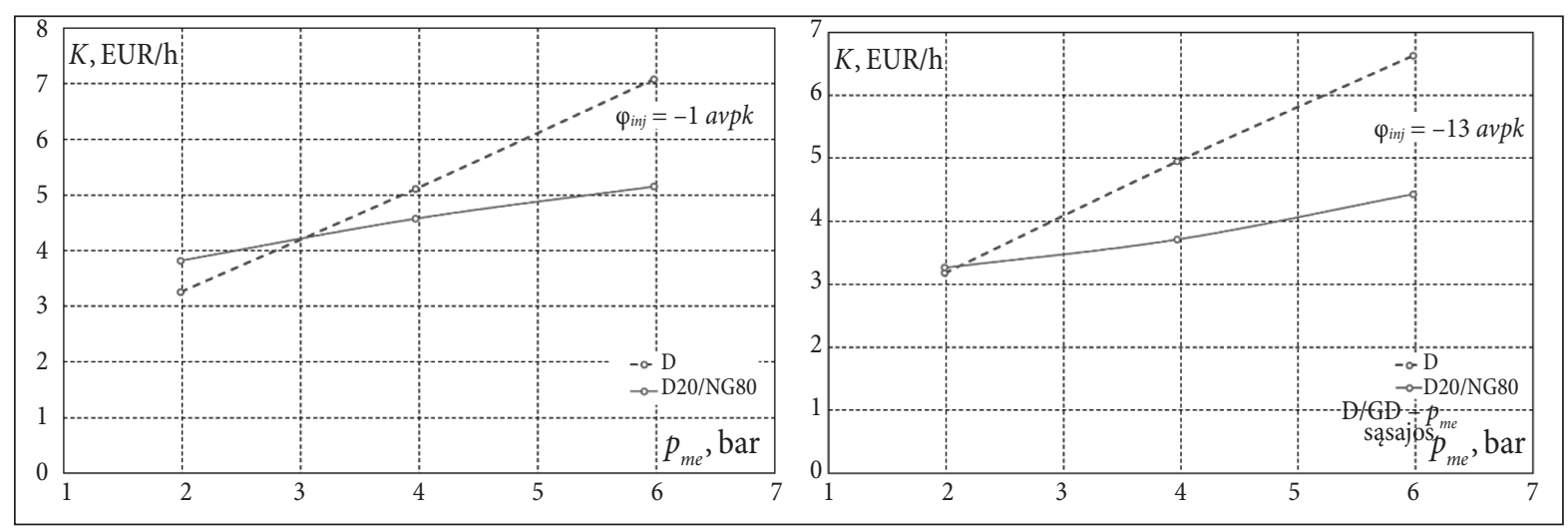

4 pav. Suminės eksergijos vieneto kaina (K), EUR/kJ dviem atvejais: varikliui naudojant D ir D/GD (20/80)

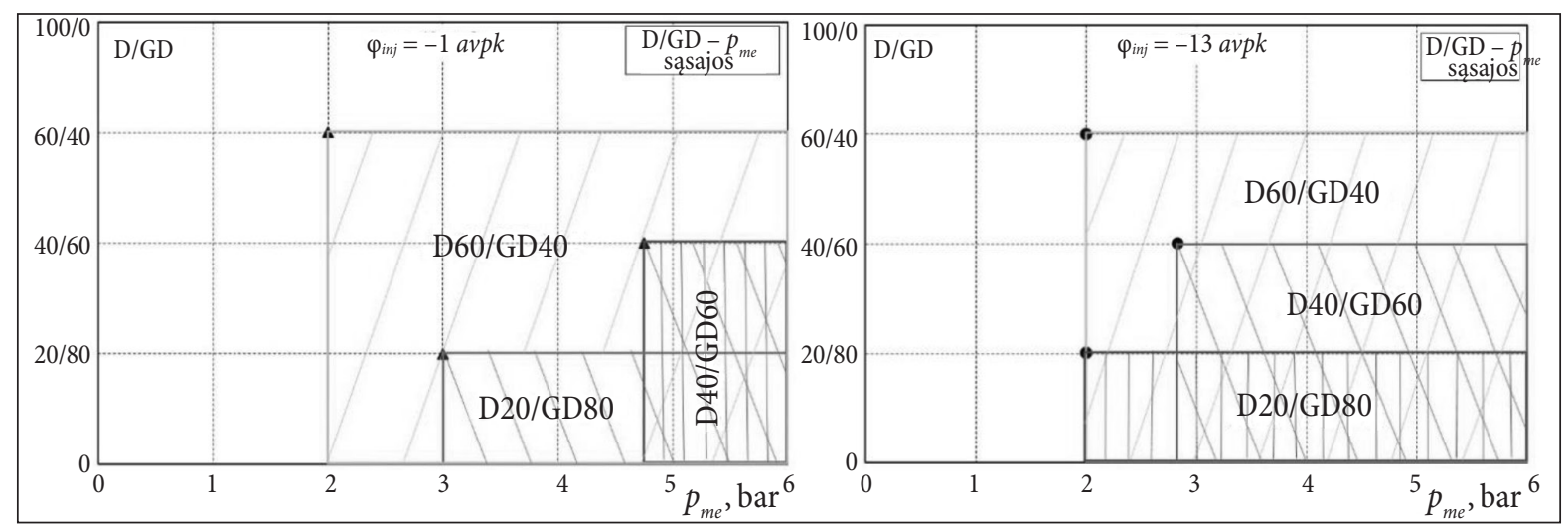

5 pav. Suminès eksergijos vieneto kaina (K), EUR/kJ dviem atvejais: varikliui naudojant D ir D/GD (20/80)

5 pav. linijų taškų kombinacijos $\mathrm{D} / \mathrm{GD}-p_{m e}$ apibūdina dvejopo kuro racionalios sudèties nustatymą, kai pasiekiama vienoda kogeneracinio ciklo praktinio panaudojimo suminès eksergijos vieneto kaina, atitinkanti dyzelino naudojimo atveji. Praktiniam panaudojimui, siekiant sumažinti vartotojams tiekiamos kogeneracinio ciklo energijos savikainą, būtina rinktis $\mathrm{D} / \mathrm{GD}-p_{m e}$ kombinacijas, išdèstytas 5 paveiksle.

\section{IŠVADOS}

1. Kogeneracinès dyzelinès jègainès su tradicine kuro tiekimo sistema konvertavimas veikimui naudojant dvejopą dyzelinas-gamtinès dujos (D/ GD) kurą lemia reikšmingus eksergijos balanso pokyčius ir energetinių sudedamụjų, mechaninès ir šiluminès energijos persiskirstymą:

1.1. ištirtame dvejopo kuro sudetties D/ $\mathrm{GD}=100 / 0 \ldots 20 / 80$ diapazone eksergijos balanso efektinis naudingumo koeficientas $\left(\eta_{E x}\right)$, charakterizuojantis energijos panaudojimo efektyvumą elektros energijos gamybai, mažeja 7-15\% aukštos apkrovos režimuose, o esant žemai apkrovai mažèja apie $40-48 \%$, palyginti su D naudojimo atveju;

1.2. eksergijos balanso suminio naudingumo koeficiento $\left(\eta_{E x \Sigma}\right)$, ivvertinančio elektros ir šiluminès energijos panaudojimo efektyvumą, sumažèjimas neviršija 3-4 \% ir $22 \%$ atitinkamai aukštos ir žemos jègainès apkrovos režimuose;

1.3. mažéjant eksergijos panaudojimo efektyvumo rodikliams $\left(\eta_{E x e}, \eta_{E x \Sigma}\right)$, absoliutus eksergijos potencialas praktiniam panaudojimui dèl šiluminès energijos sudedamosios augimo didèja nuo 3-18 \% aukštos apkrovos režimuose ir iki 14-58 \% žemos apkrovos režimuose;

1.4. nustatyta, kad santykinai mažesni absoliučių eksergijos balanso rodiklių pasikeitimai, būdingi dyzelinèms jègainèms su didesne indikatorinio proceso dinamika, leidžia kalbèti apie kogeneracinio ciklo energetinių sudedamųjų gerinimo potencialą, didinant indikatorinio proceso dinaminius rodiklius (pvz., ankstinant dyzelino ipurškimo paskubos kampą $\left.\varphi_{i n j}\right)$. 
2. Nustatyta, kad dèl dyzelino (D) ir gamtinių dujų (GD) rinkos kainų skirtumo kogeneracinès jègainès, naudojančios dvejopą D/GD (20/80) kurą, praktinio panaudojimo eksergijos savikaina, palyginti su D atveju, mažéja $27 \%$ žemos ir $33 \%$ aukštos jẻgainès apkrovos, eksploatacinio režimo diapazone. Praktiniam panaudojimui, siekiant sumažinti eksploatacines išlaidas, kurui sudarytos racionalios dvejopo kuro sudeties parinkimo, priklausomai nuo jègainès darbo režimo, diagramos $\left(\mathrm{D} / \mathrm{GD}-p_{m e}\right)$.

\section{Pagrindiniai žymèjimai}

VRT - viršutinis rimties taškas

avpk - alkūninio veleno pasukimo kampas

$\varphi_{i n j}$ - kuro ịpurškimo paskubos kampas

$p_{m e}$ - vidutinis efektinis slègis

$T_{t}$ - išmetamụjų deginių temperatūra už turbinos

$T_{v}^{\prime}$ - įeinančio vandens temperatūra

$T_{v}^{\prime \prime}$ - išeinančio vandens temperatūra

$G_{f}$ - kuro sąnaudos

$H_{\check{z}}$ - kuro žemutinè šiluminè vertè

$\alpha_{\Sigma}$ - oro (oksidatoriaus) pertekliaus koeficientas

$\eta_{E x e}$ - efektinis naudingumo koeficientas

$Q_{f}$ - kuro ir oksidatoriaus degimo šiluma

$Q_{i d}$ - išmetamụjų deginių šiluma

$Q_{v}-$ aušinimo kontūro vandens šiluma

$\eta_{E x \Sigma}$ - eksergijos balanso suminis naudingumo koeficientas

$E x_{\Sigma}-$ dvejopo kuro kogeneracinès jejgainès suminè eksergija

$I_{k}$ - išlaidos dvejopam kurui

$K$ - suminès eksergijos vieneto kaina

Gauta 20190704 Priimta 20190730

\section{Literatūra}

1. White Paper on transport. Roadmap to a single European transport area - Towards a competitive and resource-efficient transport system. Luxembourg: Publications Office of the European Union, 2011. 28 p.

2. Directive 2014/94/EU of the European Parliament and of the Council of 22 October 2014 on the deployment of alternative fuels infrastruc- ture. Official Journal of the European Union. 2014. L 307/1.

3. International Convention for the Prevention of Pollution from Ships MARPOL 73/78. Annex VI: Regulations for the Prevention of Air Pollution from Ships. 2000.

4. Feidt M., Costea M. Energy and exergy analysis and optimization of combined heat and power systems. Comparison of various systems. Energies. 2012. Vol. 5. Iss. 9. P. 3701-3722.

5. Yousefi A., Birouk M., Guo H. An experimental and numerical study of the effect of diesel injection timing on natural gas/diesel dual-fuel combustion at low load. Fuel. 2017. Vol. 203. P. 642-657.

6. García Valladolid P., Tunestål P., Monsalve-Serrano J., García Martínez A., Hyvönen J. Impact of diesel pilot distribution on the ignition process of a dual fuel medium speed marine engine. Energy Conversion and Management. 2017. Vol. 149. P. 192-205.

7. Papagiannakis R., Rakopoulos C., Hountalas D., Rakopoulos D. Emission characteristics of high speed, dual fuel, compression ignition engine operating in a wide range of natural gas/diesel fuel proportions. Fuel. 2010. Vol. 89. P. 1397-1406.

8. Zhang C., Song J. Experimental study of co-combustion ratio on fuel consumption and emissions of NG-diesel dual-fuel heavy-duty engine equipped with a common rail injection system. Journal of Energy Institute. 2016. Vol. 89. P. 578-585.

9. Chen Z., Yao C., Wang Q., Han G., Dou Z., Wie H., Wang B., Liu M., Wu T. Study of cylinder-to-cylinder variation in a diesel engine fueled with diesel/methanol dual fuel. Fuel. 2016. Vol. 170. P. 67-76.

10. European Environment Agency EEA Report No 13/2017. Air quality in Europe - 2017 report.

11. Ramos da Costa Y. J., Barbosa de Lima G. A., Bezerra Filho C. R., Lima L. A. Energetic and exergetic analyses of a dual-fuel diesel engine. Renewable and Sustainable Energy Reviews. 2012. Vol. 16. Iss. 7. P. 4651-4660.

12. Lebedevas S., Pukalskas S., Daukšys V., Rimkus A., Melaika M., Jonika L. Research on fuel efficiency and emissions of converted diesel 
engine with conventional fuel injection system for operation on natural gas. Energies. 2019. Vol. 12. Iss. 12. Article 2413.

13. Mollenhauer K., Tschoeke H. (eds.). Handbook of Diesel Engines. Springer, 2010.

14. Erofeev V. L., Zhukov V. A., Pryachin A. S. Energy and exergy approaches to assessment enhance the efficiency of heat engines. Vestnik gosudarstvennogo universiteta morskogo i rechno-go flota imeni admirala S. O. Makarova. 2017. Vol. 9. Iss. 5. P. 1017-1026 (in Russian).
Vygintas Daukšys, Sergèjus Lebedevas

COMPARATIVE RESEARCH

OF THE DUAL-FUEL ENGINE EXERGY

BALANCE

\section{Summary}

The article presents the results of diesel (D) - natural gas (GD) dual-fuel (D/GD) cogeneration cycle energy analysis for the functioning of the diesel engine " $4 \check{C} \mathrm{~N}$ $79.5 / 95.5$ ". For the purpose of the research, a comparative analysis of the energy efficiency of the dual-fuel (D/ GD) fuel-powered cogeneration cycle (exhaust gas and cooling circuit water) was used. Heat and exergy balances were tested in a wide range of load $\left(p_{m e}=1.98-\right.$ 5.99 bar) and D/DG composition (100/0-20/80) and engine adjustment parameters. The transfer of a cogeneration diesel power plant with a conventional fuel supply system to dual-fuel diesel-natural gas (D/GD) is driven by significant changes in exergy balance and energy component, mechanical and thermal energy redistribution. Exergy balance efficiency coefficient $\left(\eta_{E x e}\right)$, which characterizes the potential for efficiency in electricity production, decreases by $7-15 \%$ in high load modes, and by 40-48\% during low load drops compared to D usage. Absolute exergy potential for practical use increases due to thermal energy component growth by $3-18 \%$ in high load modes and up to $14-58 \%$ in low load modes.

Keywords: diesel engine, dual fuel, exergy 